\title{
Cdk5 and Foxc2 - a new relationship in the lymphatic vasculature
}

\author{
Johanna Lieb| ${ }^{1}$ \\ ${ }^{1}$ Ludwig Maximilians-University Munich, Department of Pharmacy, Pharmaceutical Biology, Munich, Germany \\ Correspondence to: Johanna Liebl, email: johanna.lieb/@cup.uni-muenchen.de \\ Keywords: chromosome section, Cdk5, Foxc2, lymphatic vessels, lymphatic valves \\ Received: June 19,2015 Accepted: June 23, $2015 \quad$ Published: July 13, 2015
}

This is an open-access article distributed under the terms of the Creative Commons Attribution License, which permits unrestricted use, distribution, and reproduction in any medium, provided the original author and source are credited.

\section{ABSTRACT}

Lymphatic vessel dysfunction is associated with various pathologic conditions, including immunologic disorders, lymphedema, as well as tumor dissemination. Yet, the knowledge about the regulation of lymphatic vessel development is still limited. Our study elucidates cyclin dependent kinase 5 (Cdk5) as an essential player in the development of lymphatic vessels. Deletion of Cdk5 in the mouse endothelium results in severe lymphedema formation and embryonic lethality. On the mechanistic level, we show that Cdk5 phosphorylates the forkhead transcription factor Foxc2 which regulates Foxc2-dependent transcription. In summary, our study elucidates the Cdk5Foxc2 interaction as a critical regulator of lymphatic vessel development.

The lymphatic system is essential for the maintenance of tissue fluid homeostasis, enables the uptake of dietary lipids and regulates the immune response by serving as a trafficking route for immune cells [1]. Lymphatic vessel formation starts after the circulatory system has been established by specification of lymphatic endothelial cells from preexisting embryonic veins. The primary lymph sacs are formed and get separated from the cardinal vein by the formation of lymphovenous valves. Primary lymphatic vessels remodel into blind ending lymphatic capillaries that take up interstitial fluid and collecting lymphatic vessels that contain valves, are covered by smooth muscle cells and drain the lymph into the venous system [2].

Malfunctioning of the lymphatic system is associated with various pathologic conditions. Dysfunction of the lymphatic vasculature results in lymphedema formation and compromises immune function. Moreover, the lymphatic system contributes to tumor cell metastasis - tumors induce lymphangiogenesis to allow the dissemination of tumor cells [3].

The forkhead transcription factor Foxc2 plays a central role in lymphatic vessel development and lymphatic valve formation [4-6]. Mutations in the Foxc2 gene cause lymphedema-distichiasis, a human disease with severe lymphedema and double rows of eyelashes $[7,8]$. Moreover, Foxc2 has been associated with cancer cell metastasis and epithelial-mesenchymal transition [9,
10]. Recently, it has been shown that phosphorylation regulates Foxc2-mediated transcription in lymphatic endothelial cells [11]. However, a kinase responsible for Foxc2 phosphorylation has not been identified.

Our recent study elucidates the serine-threonine kinase cyclin dependent kinase $5(\mathrm{Cdk} 5)$ as the missing link in the regulation of Foxc2 in the lymphatic endothelium [12]. The "neuronal kinase" Cdk5 has been supposed to be neuron-specific for a long time due to its essential function in CNS development, function and disease. Although, recently, the awareness about extraneuronal functions of Cdk5 has grown and Cdk5 was for example associated with cancer, inflammation, or metabolism [13, 14], our knowledge about Cdk5 in the periphery is still insufficient. Only few studies including our own pointed to a function of Cdk5 in the endothelium [15-17] and until now, a detailed study investigating the in vivo function of $\mathrm{Cdk} 5$ in the endothelium was still missing.

By using endothelial-specific Cdk5 knockout mouse models, our recent work demonstrated that $\mathrm{Cdk} 5$ is essential for lymphatic vessel development. Endothelialspecific deletion of Cdk5 causes congenital lymphatic dysfunction with lymphedema and finally results in embryonic lethality. Cdk5 knockdown embryos develop non-separation of blood and lymphatic vessels and show severe defects in lymphatic valve formation and lymphatic vessel patterning with ectopic coverage of lymphatic 


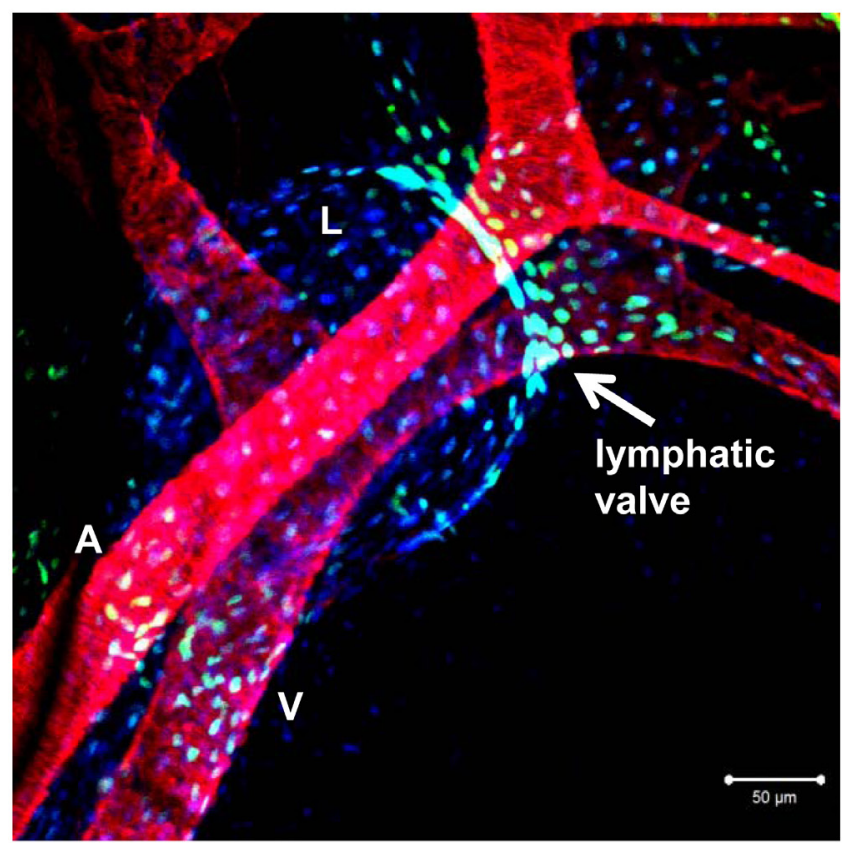

Control

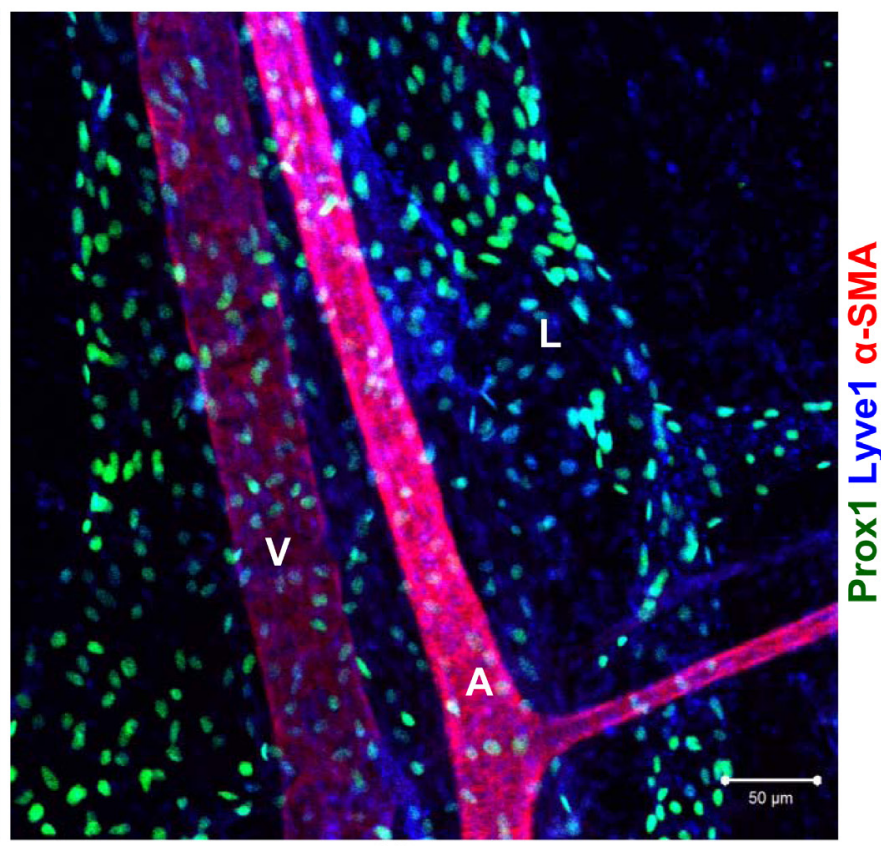

Cdk5 $5^{f / f \mid}$ Tie2Cre

Defective lymphatic valve formation in endothelial-specific Cdk5 knockout mice. Whole-mount immunostainings of mesenteric vessels of control and Cdk5 knockout (Cdk5fl/fl/Tie2Cre) embryos (E18.5) are shown. Prox1 (green) and Foxc2 (blue) stain lymphatic endothelial cells, $\alpha$-smooth muscle actin ( $\alpha$-SMA) stains artery and vein. A lymphatic valve can be recognized by high expression of Prox1 and Foxc2 and is indicated by the arrow in the left picture. A: artery; V: vein; L: lymphatic vessel.

vessels by smooth muscle cells. As the underlying mechanism, we identified Cdk5 as the upstream kinase of Foxc2. Cdk5 phosphorylates Foxc2 and activates Foxc2-dependent transcription. As a consequence, Cdk5-mediated phosphorylation of Foxc2 regulates the expression of Foxc2-dependent target genes. Among others, connexin 37, a downstream target gene of Foxc2 that is crucial for lymphatic valve formation $[6,18]$, was strongly diminished in the lymphatic endothelium of Cdk5 deficient mice.

Collectively, our findings elucidate the Cdk5-Foxc2 interaction as a critical regulator of the transcriptional network underlying lymphatic vascular remodeling and thereby provide novel insight into the regulation of lymphatic vessel development. Moreover, because Cdk5 represents a drugable kinase [16,17], our work implicates $\mathrm{Cdk} 5$ as a potential target for the treatment of diseases associated with lymphatic dysfunction.

\section{REFERENCES}

1. Tammela T and Alitalo K. Lymphangiogenesis: Molecular mechanisms and future promise. Cell. 2010; 140:460-476.

2. Schulte-Merker S, Sabine A and Petrova TV. Lymphatic vascular morphogenesis in development, physiology, and disease. J Cell Biol. 2011; 193:607-618.

3. Alitalo K. The lymphatic vasculature in disease. Nat Med. 2011; 17:1371-1380.
4. Petrova TV, Karpanen T, Norrmen C, Mellor R, Tamakoshi T, Finegold D, Ferrell R, Kerjaschki D, Mortimer P, YlaHerttuala S, Miura N and Alitalo K. Defective valves and abnormal mural cell recruitment underlie lymphatic vascular failure in lymphedema distichiasis. Nat Med. 2004; 10:974-981.

5. Norrmen C, Ivanov KI, Cheng J, Zangger N, Delorenzi M, Jaquet M, Miura N, Puolakkainen P, Horsley V, Hu J, Augustin HG, Yla-Herttuala S, Alitalo K and Petrova TV. FOXC2 controls formation and maturation of lymphatic collecting vessels through cooperation with NFATc1. J Cell Biol. 2009; 185:439-457.

6. Sabine A, Agalarov Y, Maby-El Hajjami H, Jaquet M, Hagerling R, Pollmann C, Bebber D, Pfenniger A, Miura $\mathrm{N}$, Dormond O, Calmes JM, Adams RH, Makinen T, Kiefer F, Kwak BR and Petrova TV. Mechanotransduction, PROX1, and FOXC2 cooperate to control connexin 37 and calcineurin during lymphatic-valve formation. Dev Cell. 2012; 22:430-445.

7. Fang J, Dagenais SL, Erickson RP, Arlt MF, Glynn MW, Gorski JL, Seaver LH and Glover TW. Mutations in FOXC2 (MFH-1), a forkhead family transcription factor, are responsible for the hereditary lymphedema-distichiasis syndrome. Am J Hum Genet. 2000; 67:1382-1388.

8. Finegold DN, Kimak MA, Lawrence EC, Levinson KL, Cherniske EM, Pober BR, Dunlap JW and Ferrell RE. Truncating mutations in FOXC2 cause multiple lymphedema syndromes. Hum Mol Genet. 2001; 10:11851189. 
9. Mani SA, Yang J, Brooks M, Schwaninger G, Zhou A, Miura N, Kutok JL, Hartwell K, Richardson AL and Weinberg RA. Mesenchyme Forkhead 1 (FOXC2) plays a key role in metastasis and is associated with aggressive basal-like breast cancers. Proc Natl Acad Sci U S A. 2007; 104:10069-10074.

10. Hollier BG, Tinnirello AA, Werden SJ, Evans KW, Taube JH, Sarkar TR, Sphyris N, Shariati M, Kumar SV, Battula VL, Herschkowitz JI, Guerra R, Chang JT, Miura N, Rosen JM and Mani SA. FOXC2 expression links epithelialmesenchymal transition and stem cell properties in breast cancer. Cancer Res. 2013; 73:1981-1992.

11. Ivanov KI, Agalarov Y., Valmu L., Samuilova O., Nawal H., Maby-El Hajjami H., Norrmen C., Jaquet M., Miura, N., Zangger N., Ylä-Herttuala S., Delorenzi M., Petrova T.V. Phosphorylation regulates FOXC2-mediated transcription in lymphatic endothelial cells. Molecular and Cellular Biology. 2013.

12. Liebl J, Zhang S, Moser M, Agalarov Y, Demir CS, Hager B, Bibb JA, Adams RH, Kiefer F, Miura N, Petrova TV, Vollmar AM and Zahler S. Cdk5 controls lymphatic vessel development and function by phosphorylation of Foxc2. Nat Commun. 2015; 6:7274.

13. Liebl J, Furst R, Vollmar AM and Zahler S. Twice switched at birth: cell cycle-independent roles of the "neuronspecific" cyclin-dependent kinase 5 (Cdk5) in non-neuronal cells. Cell Signal. 2011; 23:1698-1707.

14. Contreras-Vallejos E, Utreras E and Gonzalez-Billault C. Going out of the brain: non-nervous system physiological and pathological functions of Cdk5. Cell Signal. 2012; 24:44-52.

15. Liebl J, Weitensteiner SB, Vereb G, Takacs L, Furst R, Vollmar AM and Zahler S. Cyclin-dependent kinase 5 regulates endothelial cell migration and angiogenesis. J Biol Chem. 2010; 285:35932-35943.

16. Liebl J, Krystof V, Vereb G, Takacs L, Strnad M, Pechan P, Havlicek L, Zatloukal M, Furst R, Vollmar AM and Zahler S. Anti-angiogenic effects of purine inhibitors of cyclin dependent kinases. Angiogenesis. 2011; 14:281-291.

17. Weitensteiner SB, Liebl J, Krystof V, Havlicek L, Gucky T, Strnad M, Furst R, Vollmar AM and Zahler S. Trisubstituted pyrazolopyrimidines as novel angiogenesis inhibitors. PLoS One. 2013; 8:e54607.

18. Kanady JD, Dellinger MT, Munger SJ, Witte MH and Simon AM. Connexin37 and Connexin43 deficiencies in mice disrupt lymphatic valve development and result in lymphatic disorders including lymphedema and chylothorax. Dev Biol. 2011; 354:253-266. 